\title{
Gelatin capsule waste: new source of protein to develop a biodegradable film
}

\author{
Camila de Campo ${ }^{1}$, Carlos Henrique Pagno ${ }^{1}$, Tania Maria Haas Costa ${ }^{1,2}$, Alessandro de Oliveira Rios ${ }^{1}$ and \\ Simone Hickmann Flôres ${ }^{1 *}$ \\ 'Laboratório de Compostos Bioativos, Instituto de Ciência e Tecnologia de Alimentos, \\ Universidade Federal do Rio Grande do Sul - UFRGS, Porto Alegre, RS, Brazil \\ ${ }^{2}$ Instituto de Química, Universidade Federal do Rio Grande do Sul - UFRGS, Porto Alegre, RS, Brazil \\ *simone.flores@ufrgs.br
}

\begin{abstract}
This work aimed to develop biodegradable films utilizing a new source of gelatin derived from the nutraceutical capsule manufacture waste of coconut with safflower oil, coconut oil and safflower oil. The mechanical, physicochemical, barrier, optical, biodegradation, thermal and morphological properties were evaluated. All films showed low water vapor permeability, intermediate water solubility and high elongation at break. In addition, the films exhibited excellent barrier ability to ultraviolet light. After 15 days of soil burial degradation, the films lost over $68 \%$ of initial weight. Scanning electron microscopy showed an appearance free of pores, cracks or bubbles. Furthermore the films showed similar characteristics independent of the waste utilized. The results demonstrated that all the biodegradable films prepared presented appropriate characteristics to be used as substitute to synthetic packaging.
\end{abstract}

Keywords: gelatin films, food packaging, nutraceutical capsules waste, environmental impact.

\section{Introduction}

The development of biodegradable film is an environmentally friendly technology that would permit a reduction in the impact and costs associated with polymers from non-renewable sources. There is growing interest, mainly from industry, regard to the preparation of packages that promote a greater product shelf life and having an environmental appeal, and there is reciprocal consumer interest in purchasing this type of product ${ }^{[1]}$.

One of the alternatives for the biodegradable films production is the use of new materials. Polymers obtained from renewable resources or valorization of industrial wastes and by-products are considered a good alternative to reduce environmental impacts and costs ${ }^{[2]}$. The wastes may contain many substances of high value and if appropriate technology is employed, these materials can be converted into commercial products or raw materials for secondary processes. Numerous substances related to the food production process are suitable for separation and reuse ${ }^{[3]}$, such as chitosan (derived from marine wastes) and soy by-products from soy oil industry ${ }^{[4]}$.

An interesting waste to produce biodegradable films is obtained from the manufacture of nutraceutical capsules. These wastes present a good source for the preparation of biodegradable films with desirable characteristics due to its composition (glycerol, gelatin and water). The production of nutraceutical capsules generates a large amount of waste that cannot be reused for the industry and is disposed of into the environment. Its use in other applications is of great interest to the nutraceutical industry because it would significantly reduce environmental problems as well as costs generated to its treatment. The gelatin waste from the manufacture of nutraceutical capsules can be considered a new source of protein and has a high glycerol content naturally present in its composition. The glycerol provides better mechanical properties, forming films more stretchable and flexible $\mathrm{e}^{[4]}$, due to the reduction of intermolecular forces and increase on the mobility of polymeric chains. Vanin et al. ${ }^{[5]}$ observed that glycerol was compatible with gelatin, and exhibited the highest plasticizing effect on the mechanical properties, producing a flexible film without phase separation.

Considering the possibility of use gelatin capsule waste as a promising material to produce biodegradable films and as an alternative for the reuse of this waste, the study aimed to develop a novel biodegradable film formulated from nutraceutical capsule manufacture waste of coconut with safflower oil, coconut oil and safflower oil and to characterize mechanical, physicochemical, barrier, optical, biodegradation, thermal and morphological properties, to develop a more sustainable material, adding value to this waste.

\section{Materials and Methods}

The material used in this work was gelatin nutraceutical capsules waste provided by the Laboratory Chemical Pharmaceutical Tiaraju, located in Santo Angelo - RS. The gelatin used to produce the capsules was from bovine source. The wastes are basically composed of water (30\%), glycerin (21.8\%) and gelatin (48.2\%). For the film preparation, the waste derived from the production of coconut with safflower oil, coconut and safflower nutraceutical capsules were utilized. 


\subsection{Film preparation}

Gelatin films were prepared by casting. For the preparation of the filmogenic solution, $50 \mathrm{~g}$ of waste was dissolved in $70 \mathrm{~mL}$ of distilled water (conditions defined according to preliminary tests) in a water bath (Model 752A, Mark Fisatom) under constant stirring to melt the network at $60^{\circ} \mathrm{C}$ for 30 minutes. The filmogenic solution was then placed in a vacuum desiccator for 2 minutes to remove air bubbles. Then, $0.13 \mathrm{~g} / \mathrm{cm}^{2}$ (corresponding to $20 \mathrm{~g}$ of the filmogenic solution), was weighed, placed in polystyrene Petri plates and dried in an oven with air circulation (Model B5AFD, Mark DeLeo) at $35^{\circ} \mathrm{C}$ for 18 hours.

\subsection{Film characterization}

The films were conditioned in desiccators under a controlled relative humidity of $58 \%$ at $25^{\circ} \mathrm{C}$, containing a saturated solution of sodium bromide $(\mathrm{NaBr})$ for $48 \mathrm{~h}$ until their characterization ${ }^{[6]}$.

\subsubsection{Film thickness measurement}

The film thickness was determined using a digital micrometer (Model MDC-25, Mitutoyo Corp. Tokyo, Japan) with a range of 0 to $25 \mathrm{~mm}$ and a precision of $0.001 \mathrm{~mm}$. The values represent the average of five measurements made randomly along each sample evaluated and the final thickness is the arithmetic average of five points of each random sample.

\subsubsection{Mechanical properties}

The mechanical properties of films were evaluated by tensile strength (TS) [MPa], elongation at break (E) [\%] using a Texture analyzer (Model TA.XT2i, Mark Stable Micro Systems, UK) with a load cell of $5 \mathrm{~kg}$, using the A/TGT self-tightening roller grips fixture, according to ASTM $^{[7]}$. Film specimen strips $(80-25 \mathrm{~mm})$ were cut and their thickness was measured using a micrometer at three random positions along each strip. Ten strips were cutted, and each one was held between the grips of the equipment for testing with the initial distance between the grip and test speed set to $50 \mathrm{~mm}$ and $0.8 \mathrm{~mm} \mathrm{~s}^{-1}$, respectively.

\subsubsection{Moisture content}

Moisture content was determined according to Liu et al. ${ }^{[8]}$. The prepared film samples ( $2 \mathrm{~cm}$ in diameter) were dried in an oven (Model B5 AFD, Mark DeLeo) at $105^{\circ} \mathrm{C}$ for $24 \mathrm{~h}$, and their moisture content was analyzed gravimetrically.

\subsubsection{Water solubility}

The water solubility was performed according to Colla et al. ${ }^{[9]}$, with some modifications. The solubility was calculated as the percentage of dry matter of the film solubilized after immersion for $24 \mathrm{~h}$ in water at $25^{\circ} \mathrm{C}$. Discs of the film (2-cm diameter) were cut, weighed, immersed in $30 \mathrm{~mL}$ of distilled water, and slowly and periodically agitated. The amount of dry matter of the initial and final samples was determined by drying the samples at $105^{\circ} \mathrm{C}$ for $24 \mathrm{~h}$. Afterwards, the samples were filtered using desiccated pre-weighed filter paper. The filter paper, containing undissolved fragments of film, was dried at $105{ }^{\circ} \mathrm{C}$ for $24 \mathrm{~h}$ in an oven (Mark DeLeo, model TLK 48, Brazil), and the resulting material was weighed for the determination of the final dry weight $\left(W_{F}\right)$. The solubility was calculated by Equation 1:

$$
W S(\%)=\frac{W i-W f}{W i} \times 100
$$

where wi is the initial dry weight of the sample (g), and wf is the final dry weight of the sample $(\mathrm{g})$.

\subsubsection{Water Vapor Permeability (WVP)}

The WVP was determined gravimetrically, according to the method described by Mei et al. ${ }^{[10]}$ with some modifications. The samples were placed in permeation cells (inner diameter: $63 \mathrm{~mm}$, height: $25 \mathrm{~mm}$ ), filled with granular anhydrous calcium chloride and hermetically sealed. The permeation cells were placed in a glass chamber with a saturated sodium chloride solution, providing $\mathrm{RH}$ gradients of $75 \%$ at $25^{\circ} \mathrm{C}$. Mass gain was determined by weighing the permeation cells on an analytical balance (AY 220, Shimadzu) at intervals at $1 \mathrm{~h}, 12 \mathrm{~h}$ and $24 \mathrm{~h}$. The water vapor permeability of the samples was determined in triplicate by Equation 2:

$$
W V P=\frac{W . L}{\text { A.t. } \Delta \mathbf{P}}
$$

where $\mathrm{W}$ is the weight of water permeated through the film (g), L is the film thickness ( $\mathrm{m})$, A is the permeation area $\left(\mathrm{m}^{2}\right)$, $\mathrm{t}$ is the time of permeation (h), and $\Delta \mathrm{p}$ is the water vapor pressure difference between the two sides of the film $(\mathrm{Pa})$.

\subsubsection{Opacity}

The opacity was determined by measuring the film absorbance at 210 and $500 \mathrm{~nm}$ using a UV spectrophotometer (model Shimadzu UV-1800). Films were cut into a rectangle piece and directly placed in a spectrophotometer test cell. An empty test cell was used as reference. The film opacity was calculated dividing the absorbance values $(\mathrm{nm})$ by the film thickness $(\mathrm{mm})$. All determinations were performed in triplicate ${ }^{[1]}$.

\subsubsection{Thermal properties}

The gelatin film samples were submitted to thermogravimetric analysis (TGA), using nitrogen atmosphere, according to the methodology described by Tongnuanchan et al. ${ }^{[12]}$, with some modifications. The equipment used was a Shimadzu model TGA-50. The samples were heated from room temperature to $650^{\circ} \mathrm{C}$ at a rate of $10^{\circ} \mathrm{C} \mathrm{min}^{-1}$.

\subsubsection{Morphological properties}

Surface and cross-section morphology of films were visualized using Scanning Electron Microscopy (SEM). The dried film samples were mounted on aluminum stubs with double-sided adhesive tape, coated with a thin layer of platinum, and observed on a Scanning Electron Microscope (Model JSM 5800) at an acceleration voltage of $5 \mathrm{kV}$ with a magnification of 200 times to the original specimen size.

\subsubsection{Biodegradability: Indoor soil burial degradation}

The determination of soil burial degradation was performed according to Martucci and Ruseckaite ${ }^{[13]}$. Natural organic soil was used as the degradation environment for the films, which was added in plastic boxes $(6 \mathrm{~cm} \times 6 \mathrm{~cm} \times 6.5 \mathrm{~cm})$. 
The film samples were cut into rectangles $(2 \mathrm{~cm} \times 3 \mathrm{~cm})$ and dried at $60{ }^{\circ} \mathrm{C}$ in an oven (model TLK48, DeLeo, Brazil) until constant weight $\left(\mathrm{m}_{0}\right)$, and placed into an aluminum mesh, that were buried at the depth of $4 \mathrm{~cm}$ from the surface of the natural organic soil. Every 2 days, water was added to the soil to maintain the humidity. The degradation degree of the films was determined after 15 days as the weight loss (WL; \%) by Equation 3:

$$
W L(\%)=\frac{m t-m 0}{m 0} \times 100
$$

where $\mathrm{m}_{0}$ is the initial mass and $\mathrm{m}_{\mathrm{t}}$ the remaining dried mass after 15 days.

\subsection{Statistical analysis}

All analyses were performed in triplicate, and the results were evaluated by an analysis of variance (ANOVA) and Tukey's test at a significance level of 0.05 using the software Statistica 12.0 (Statsoft Inc., São Paulo, Brazil).

\section{Results and Discussion}

The resulting film emulsion of the three gelatin capsules waste analyzed were composed of glycerin (15\%), gelatin $(28.3 \%)$ and water $(56.7 \%)$. Gelatin has been known to form clear, flexible, strong and oxygen-impermeable films when cast from aqueous solutions in the presence of plasticizer. Edible films with gelatin reduce oxygen, moisture, and oil migration and can carry antioxidants or antimicrobial agents $^{[14]}$. Due to the hydrophilic nature of these films, they can be used as good gas barriers, but they have poor water barriers.

Al-Hassan and Norziah ${ }^{[15]}$, analyzed fish skin gelatin used for the development of films and found $81.3 \%$ for soluble protein. They developed films with starch and different protein mixtures, and the films with higher content of protein presented $21,6 \%$ of protein, lower values than those obtained in this study. The high protein content induced to form films with higher elongation at break. Thus, the gelatin capsules waste based films showed higher capacity to form more elastic films. Proteins have good adherence to hydrophilic surfaces and serve as good barriers against $\mathrm{O}_{2}$ and $\mathrm{CO}_{2}{ }^{[16]}$, thus, the higher amount of it helps to improve these characteristics.

\subsection{Film thickness}

As observed in Table 1, the thickness of the films did not present a significant difference independent of the waste utilized. Carvalho ${ }^{[17]}$, evaluated the thickness of cassava starch and soy protein films and found values lower than all films in this study (0.107-0.132 mm). Cozmuta et al. ${ }^{[18]}$, developed gelatin films with hemp and sage oils and found similar values to those obtained in this work ( 0.182 to $0.211 \mathrm{~mm})$ and observed increase in the thickness for films with higher oil content added.

The thickness values observed in the present study, compared to previous works, indicate that the waste studied allowed the formation of films with the appropriate thickness to be mechanically resistant and suitable for food biodegradable packaging.

\subsection{Mechanical properties}

Adequate mechanical strength and extensibility are necessary for films to have resistance to external factors and suitable barrier properties for applications such as food packaging ${ }^{[19]}$. Representative stress and strain curves of the analyzed films are shown in Figure 1. The curves demonstrated the deformation behavior of the films, indicating that the films elaborated with gelatin capsule waste of safflower exhibited the higher values for elongation at break and the lower values for tensile strength, while the film developed with gelatin capsule waste of coconut with safflower, showed the higher values for tensile strength.

Table 1 shows the thickness, tensile strength (TS) and percentage elongation at break $(\mathrm{E} \%)$, of the analyzed films. The values obtained for tensile strength (TS) are similar to those found by Hosseini et al. ${ }^{[20]}$ who studied films prepared from fish skin gelatin in cold water $(2.17 \pm 0.97 \mathrm{MPa})$; however, the film elongation at break in this study is greater than that found by these authors $(82.61 \pm 20.11 \%)$. Al-Hassan and Norziah ${ }^{[15]}$, also found lower values than those obtained in this work when developing films from starch with fish

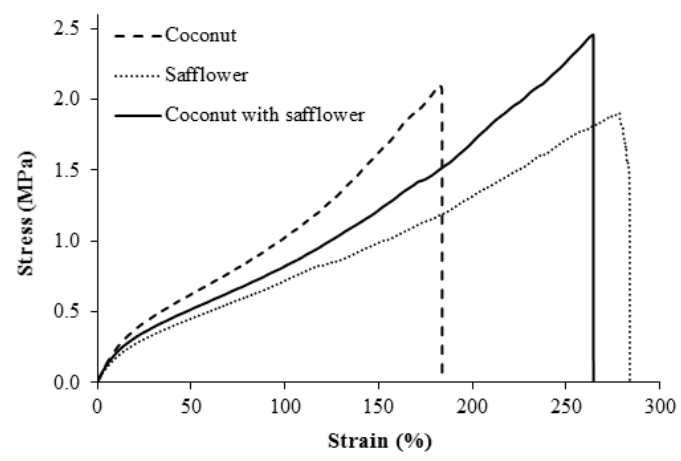

Figure 1. Stress-strain curves of nutraceutical capsule waste based films.

Table 1. Film thickness, tensile strength (TS), and elongation at break (E) of nutraceutical capsule waste based films. ${ }^{\mathrm{a}, \mathrm{b}}$

\begin{tabular}{cccc}
\hline Film & Thickness $(\mathbf{m m})$ & TS $\left.^{\mathrm{c}} \mathbf{M P a}\right)$ & $\mathbf{E}^{\mathrm{d}} \mathbf{( \% )}$ \\
\hline Coconut with safflower & $0.256 \pm 0.005^{\mathrm{a}}$ & $2.41 \pm 0.09^{\mathrm{a}}$ & $264.62 \pm 1.57^{\mathrm{b}}$ \\
Coconut & $0.212 \pm 0.04^{\mathrm{a}}$ & $2.14 \pm 0.10^{\mathrm{b}}$ & $189.10 \pm 5.79^{\mathrm{c}}$ \\
Safflower & $0.274 \pm 0.05^{\mathrm{a}}$ & $1.96 \pm 0.09^{\mathrm{c}}$ & $275.68 \pm 3.97^{\mathrm{a}}$ \\
\hline
\end{tabular}

\footnotetext{
${ }^{a}$ The results are represented as the means \pm standard deviation; ${ }^{b}$ Values with the same letter are not significantly different $(p>0.05)$;

${ }^{\mathrm{c}} \mathrm{TS}(\mathrm{MPa})=\mathrm{F} \max / \mathrm{A}\left(\mathrm{F} \max\right.$, maximum load $(\mathrm{N})$ needed to pull the sample apart; A, cross-sectional area $\left(\mathrm{m}^{2}\right)$ of the samples);

${ }^{\mathrm{d}} \mathrm{EAB}(\%)=(\mathrm{E} / 50) \times 100$ (E, film elongation $(\mathrm{mm})$ at the moment of rupture; 50, initial grip length $(\mathrm{mm})$ of samples).
} 
skin gelatin: $1.28 \mathrm{MPa}$ and $1.67 \mathrm{MPa}$ for tensile strength and values between 84 and $102 \%$ for percentage of elongation at break. Garrido et al. ${ }^{[21]}$, found higher values for tensile strength (1.55-7.50 MPa) for films produced from soya by-products with different ratios of sorbitol, but found lower values for elongation at break (3.95-117.83\%).

Comparing to commercial polymers such as LDPE (9-17 MPa) and polystyrene (35-55 MPa) the values obtained in this study for tensile strength were lower, however the majority of films presents TS values lower than the synthetic commercial polymers. On the other hand, nutraceutical capsule waste based films showed high elongation at break and the values were higher than cellophane $(20 \%)$ and polystyrene $(1 \%)^{[22]}$.

Dias et al. ${ }^{[23]}$, observed that the highest Young's modulus values $(1053 \pm 146 \mathrm{MPa})$ were found for rice starch and flour-based films with lower plasticizer content and these films with sorbitol were more inflexible than those with glycerol. The glycerol content of waste acted as a plasticizer and may have reduced the interactions between polymer chains, thereby increasing film flexibility ${ }^{[24]}$. Glycerol can be used in biodegradable films to increase their flexibility and elongation values, however reduce the values of tensile strength $^{[25]}$. The studied films presented high percent elongation at break, providing films with higher flexibility and that take a longer time to break.

In addition, hydrophobic materials, such as lipids present in the waste, can decrease the strength of films. Shellhammer and Krochta ${ }^{[26]}$, observed that increasing the lipid level, the strength of whey protein isolate (WPI) films reduced. The incorporation of Candelilla wax gave the weakest WPI films, followed by beeswax, milk fat, and carnauba wax. These authors found that the lipid also affected the tensile strength, elongation and elastic modulus of the composite films. In this work, the lipid at low concentrations present in the waste is homogeneously distributed in the polymeric matrix, resulting in good mechanical properties.

\subsection{Moisture content}

The moisture contents of gelatin films are shown in Table 2, and the values were around $20-21 \%$. There was no significant difference in the moisture content between the three different wastes utilized. Arfat et al. ${ }^{[27]}$, obtained similar values $(20-22 \%)$ for films based on fish protein isolate. Bodini et al. ${ }^{[28]}$, obtained lower values (14.7\%) for films of fish gelatin. Increasing the glycerol amount, increases the film moisture content ${ }^{[29]}$. The oil present in waste may have caused a decrease in the film moisture because the hydrophobic characteristics of the oil, that cause a decrease in water-protein interactions.

\subsection{Water solubility}

The water solubility defines the tolerance to water and is determined by the chemical structure of the materials. The desired value for the solubility depends to its application or intended use.

As observed in Table 2, the solubility in water for gelatin films was approximately $45 \%$. The high glycerol content of nutraceutical capsule waste interacts with the film matrix by increasing the space between the chains, facilitating water migration into the film and, consequently, increasing solubility ${ }^{[25]}$. Nur Hanani et al. ${ }^{[30]}$, found similar values of $40 \%$ for films prepared with fish gelatin. Hosseini et al. ${ }^{[20]}$, found an average of $64 \%$ of solubility for films from skin gelatin derived from cold water fish. In the analysis of blend films from soy protein isolate and cod gelatin, Denavi et al. ${ }^{[31]}$, observed values above $80 \%$, and justified that this value would indicate a poor water resistance, however, for some applications, the high solubility could be advantageous: for example, as a carrier of bioactive compounds, and soluble film packaging is convenient to use in ready-to-eat products as they melt in boiled water or in the consumer's mouth.

The results of this study indicate that the films exhibit intermediate solubility in water and may be applied in dry foods.

\subsection{Water Vapor Permeability (WVP)}

The Table 2 shows the results of water vapor permeability of nutraceutical capsule waste based films. Hosseini et al. ${ }^{[20]}$, studying fish gelatin films, found higher values for WVP $\left(0.826 \pm 0.047 \mathrm{~g} . \mathrm{mm} / \mathrm{h} \mathrm{m}^{2} \mathrm{kPa}\right)$. However, the results of this study were higher than synthetic films, such as high-density polyethylene film (HDPE) $\left(0.0012 \mathrm{~g} . \mathrm{mm} / \mathrm{h} \mathrm{m}^{2} \mathrm{kPa}\right)$ and polyester film $\left(0.0091 \mathrm{~g} . \mathrm{mm} / \mathrm{kPa} \mathrm{h} \mathrm{m}^{2}\right)^{[32]}$. Dias et al. ${ }^{[33]}$ obtained similar values to those found in this work ( 0.21 to $\left.0.24 \mathrm{~g} . \mathrm{mm} / \mathrm{h} \mathrm{m}^{2} \mathrm{kPa}\right)$ for films of pig hide gelatin and glycerol containing yucca extract and lecithin respectively.

The known values of the water vapor permeability are essential for defining the possible film applications. A polymer that is very permeable to water vapor may be suitable for fresh products packaging, whereas a slightly permeable film may be useful for the dehydrated products packaging ${ }^{[34]}$. The protein-protein and protein-lipid interactions forming the film matrix allowed nutraceutical capsule waste-based films to present adequate water vapor barrier properties for potential use as biodegradable packaging for dried foods.

Table 2. Water vapor permeability (WVP), water solubility, moisture content and opacity of nutraceutical capsule waste based films.,

\begin{tabular}{cccccc}
\hline Waste & $\begin{array}{c}\mathbf{W V P}^{\mathbf{c}} \\
\left.\mathbf{( g . m m} / \mathbf{m}^{\mathbf{2}} \mathbf{h ~ k P a}\right)\end{array}$ & $\begin{array}{c}\text { Water solubility } \\
\mathbf{( \% )}\end{array}$ & $\begin{array}{c}\text { Moisture Content } \\
\mathbf{( \% )}\end{array}$ & $\begin{array}{c}\text { Opacity }^{\mathrm{d}} \\
\mathbf{2 1 0 n m}\end{array}$ & $\mathbf{5 0 0 \mathbf { n m }}$ \\
\hline Coconut with safflower & $0.17 \pm 0.01^{\mathrm{a}}$ & $37.68 \pm 1.08^{\mathrm{c}}$ & $21.36 \pm 1.59^{\mathrm{a}}$ & $59.01 \pm 2.53^{\mathrm{a}}$ & $2.68 \pm 0.30^{\mathrm{a}}$ \\
Coconut & $0.22 \pm 0.06^{\mathrm{a}}$ & $45.76 \pm 4.81^{\mathrm{ab}}$ & $20.44 \pm 0.9^{\mathrm{a}}$ & $62.20 \pm 2.69^{\mathrm{a}}$ & $1.63 \pm 0.09^{\mathrm{b}}$ \\
Safflower & $0.21 \pm 0.01^{\mathrm{a}}$ & $46.23 \pm 0.23^{\mathrm{a}}$ & $20.07 \pm 1.58^{\mathrm{a}}$ & $62.43 \pm 0.85^{\mathrm{a}}$ & $2.29 \pm 0.12^{\mathrm{b}}$ \\
\hline
\end{tabular}

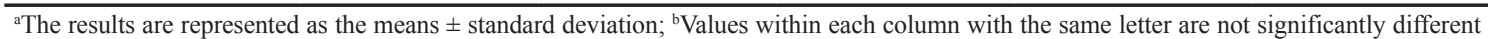
$(\mathrm{p}>0.05) ;{ }^{\mathrm{c}} \mathrm{WVP}\left(\mathrm{g} . \mathrm{mm} / \mathrm{m}^{2} \mathrm{~h} \mathrm{kPa}\right)=\left(\mathrm{w}\right.$, weight gain $(\mathrm{g})$ of the cup; $\mathrm{x}$, film thickness $(\mathrm{m}) ; \mathrm{A}$, area of exposed film $\left(\mathrm{m}^{2}\right) ; \mathrm{t}$, time of gain (h);

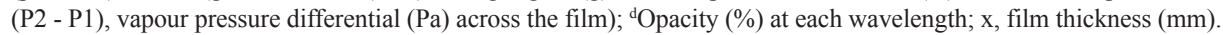




\subsection{Opacity properties}

The study of the UV light absorption capacity of the biodegradable films is important to determine their possible applications for food packaging. If these materials are able to absorb UV light, they could be used to package and extend the shelf life of fatty foods, which are susceptible to the oxidative degradation catalyzed by UV rays ${ }^{[35]}$

In the opacity, higher values indicate less transparency and high opacity ${ }^{[11]}$. According to the Table 2, when analyzed in the UV-visible $(500 \mathrm{~nm})$ region, the films showed low values, indicating that they had low absorption, which indicates greater transparency and lower opacity.

In the UV region at $210 \mathrm{~nm}$, the films showed high values, indicating a high absorption, demonstrating that these films have a high ability to protect against UV radiation, which causes the oxidative deterioration of packaged foods, leading to nutrient losses, discoloration and off-flavors ${ }^{[36]}$. This result is in agreement with previous reports on gelatinbased films ${ }^{[2,37]}$. Both studies indicate that protein-based films are considered to have high UV barrier properties, owing to their high content of aromatic amino acids, which absorb UV light.

\subsection{Thermal properties}

TGA results, showing the thermal degradation behavior of all films, are observed in Figure 2. The films showed a similar behavior considering the thermal properties studied. Three main stages of weight loss were observed for all films. The first stage was observed between 0 and $150^{\circ} \mathrm{C}$, where,

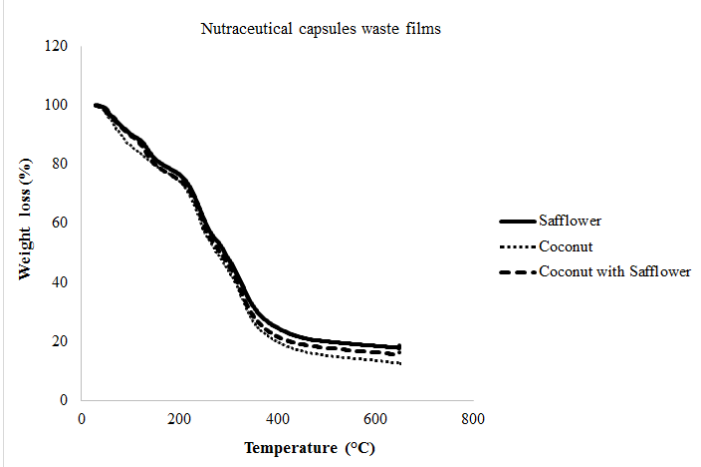

Figure 2. Thermogravimetric Analysis (TGA) curves of nutraceutical capsules waste based films. for both films, there was a loss of $20 \%$ by weight, which can be attributed to the moisture of the films. These results are in accordance with the moisture content presented before. The second stage of weight loss appeared at the onset temperature of $150-200{ }^{\circ} \mathrm{C}$ most likely due to the degradation or decomposition of lower molecular weight protein fractions and glycerol compounds. Hoque et al. ${ }^{[38]}$, also reported a degradation temperature in the range of $196-217{ }^{\circ} \mathrm{C}$ for cuttlefish skin gelatin film. For the third stage of weight loss $\left(200-450{ }^{\circ} \mathrm{C}\right)$, there was a greater loss. This was possibly due to the decomposition of highly interacted proteins in the film matrix. The results indicated that the film degradation began at $\approx 200^{\circ} \mathrm{C}$. This result is higher than those found by Nuthong et al. ${ }^{[39]}$, who reported that the initial temperature for the degradation of a porcine plasma protein-based film was observed at $170{ }^{\circ} \mathrm{C}$. The results suggested that all the films studied showed high thermal resistance. Additionally, all films had residual mass at $650{ }^{\circ} \mathrm{C}$, which represents a carbon residue of the the raw film decomposition.

\subsection{Scanning Electron Microscopy (SEM)}

The SEM provides information about the film microstructure and the interactions between film components ${ }^{[40]}$. The scanning electron microscopy of the surface and cross section of the films is shown in Figure 3 and Figure 4 respectively. The images obtained showed a surface without cracks, which suggests a cohesive matrix.

The obtained films were slightly yellow but still transparent and flexible. Their surfaces were without pores, cracks or bubbles and it was associated with the better mechanical and physical properties ${ }^{[23]}$.

However, a rough surface with small particles was observed, that may be occurred due to aggregation phenomena of lipid droplets caused by the oil naturally present in the waste during the drying step, presenting irregularities that was visualized by crystals formed at the microscopic level. Tongnuanchan et al. ${ }^{[12]}$, studying films composed of fish skin gelatin, obtained films with a homogeneous appearance but also found films with a rough surface when essential oils were incorporated. Ma et al. ${ }^{[41]}$, reported that the presence of olive oil led to the marked increases in the roughness of the films. The increase in the surface roughness is principally due to the adherence and formation of oil droplets ${ }^{[33]}$.

In the cross-section, some irregularities were also observed. Interactions in protein-protein of the film matrix might be broken due to the oil present in the composition of the films,

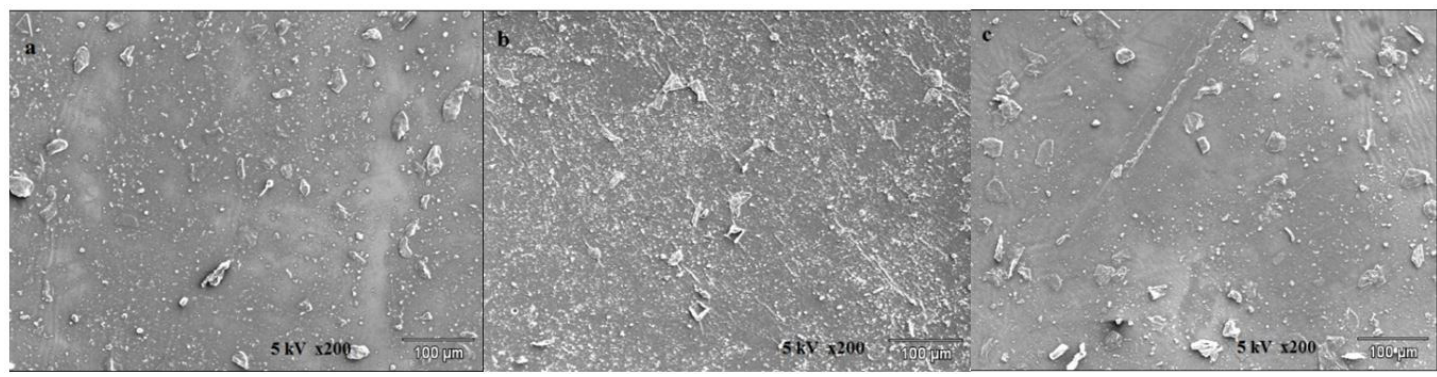

Figure 3. Scanning electron microscopy (SEM) of the surface of nutraceutical capsule waste based films of (a) coconut with safflower; (b) safflower oil; and (c) coconut oil. 


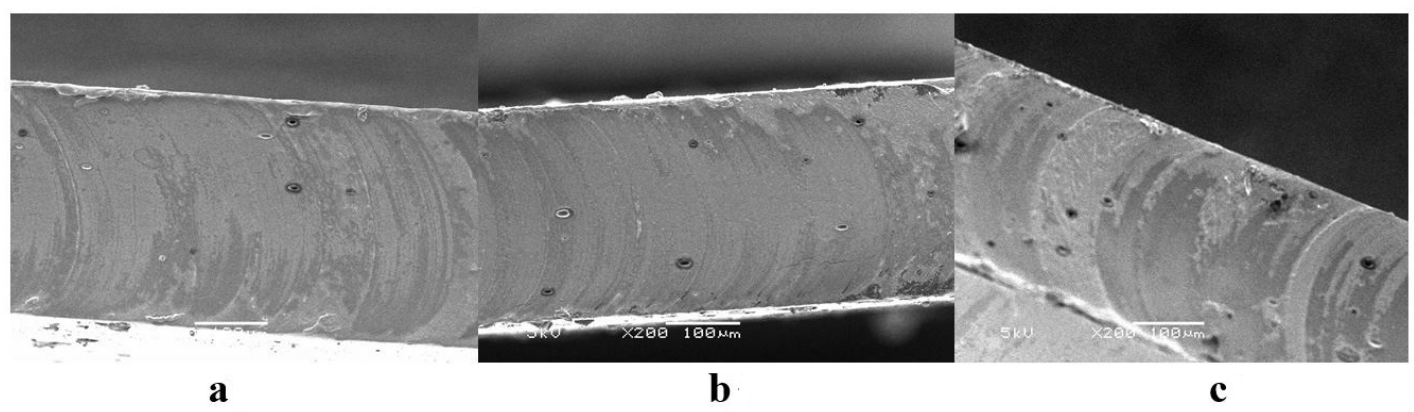

Figure 4. Scanning electron microscopy of the cross section of nutraceutical capsule waste based films of (a) coconut with safflower; (b) safflower oil; and (c) coconut oil.

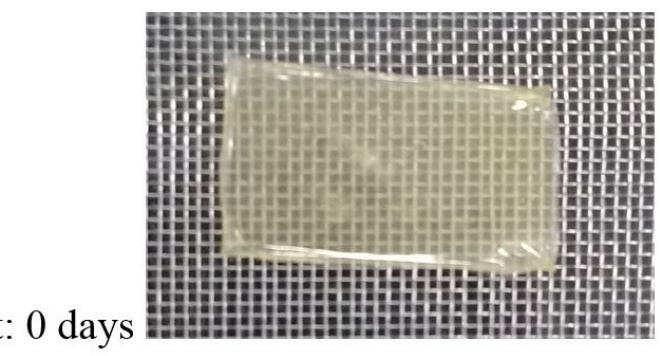

t: 15 days

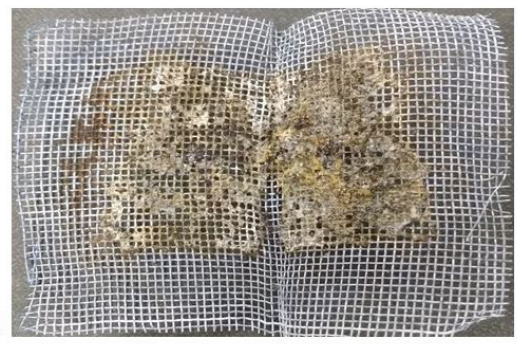

Figure 5. Visual aspect of nutraceutical capsule waste based films prior and after 15 days of incubation in soil.

providing the roughness in the cross-section ${ }^{[22]}$. The oil droplets were more localized inside the film network, and on the macroscopic level those droplets was not perceptible.

\subsection{Biodegradability: Indoor soil burial degradation}

Biodegradation study of nutraceutical capsules waste based films has been done by soil burial method, to reproduce the degradation conditions that happen in natural soil environment. The microbial population found in soil (bacteria, actinomycetes, fungi and protozoa) may act synergistically during degradation and can reproduce naturally occurring conditions $^{[13]}$. The experiment was conducted for 15 days, when the films were almost totally degraded. After this period, the films could not be recovered and evaluated, due to the macroscopic deterioration observed. Pictures of the recovered samples before and after 15 days of exposure to soil burial are shown in Figure 5. The analyzed films showed similar visual aspect independent of the waste utilized, both prior and after 15 days to exposure to soil burial degradation.

The weight loss average of the films exposed to soil environment was considered as a degradation indicator. After 15 days, all the films (independent of the waste utilized) reduced $68 \%$ of its initial weight. This lost was mostly attributed to the leaching of low-molar-mass compounds, such as glycerol. Degradation products of gelatin and glycerol might be eventually adsorbed by soil, being metabolized by microbes ${ }^{[43]}$. During soil burial the films also absorbed water, losing their initial shape.

The clear visual deterioration of the samples evidence the films susceptibility to degradation, and due this, they might be classified as rapidly degradable materials.

\section{Conclusion}

Nutraceutical capsule waste based films were successfully obtained, presenting a surface without bubbles or cracks. The gelatin films presented good mechanical properties, with high elongation at break and showed low water vapor permeability and consequently can be applied in dry foods. In addition, the films exhibited intermediate solubility in water and good absorption of ultraviolet radiation, which could provide increased protection to packaged food. The biodegradability test proved that the films are biodegradable in natural environmental conditions.

These results suggest a high potential for nutraceutical capsule manufacture waste to form biodegradable films with the appropriate characteristics for use in the food packaging industry, being an alternative to replacement non biodegradable packaging, decreasing the environmental impact. Moreover, the use of these wastes presents potential to contribute to the reduction of its amount sent to landfill, reducing environmental damage and costs, which is of great importance for industries and consumers. Further studies would be required to optimize the process condition, tensile strength and determine the specific use for films in commercial food systems.

\section{Acknowledgements}

The authors are thankful to Laboratory Chemical Pharmaceutical Tiaraju, located in Santo Angelo - RS, for supplying raw material for this research, to Coordenação de Aperfeiçoamento de Pessoal de Nível Superior (CAPES) and Fundação de Amparo à Pesquisa no Estado do Rio 
Grande do Sul (FAPERGS) for the financial support. The authors are also grateful to the Eletronic Microscopy Center of UFRGS, for their assistance in the use of SEM.

\section{References}

1. Mariniello, L., Di Pierro, P., Esposito, C., Sorrentino, A., Masi, P., \& Porta, R. (2003). Preparation and mechanical properties of edible pectin-soy flour films obtained in the absence or presence of transglutaminase. Journal of Biotechnology, 102(2), 191-198. PMid:12697396. http://dx.doi.org/10.1016/ S0168-1656(03)00025-7.

2. Tongnuanchan, P., Benjakul, S., \& Prodpran, T. (2012). Properties and antioxidant activity of fish skin gelatin film incorporated with citrus essential oils. Food Chemistry, 134(3), 1571-1579. PMid:25005982. http://dx.doi.org/10.1016/j. foodchem.2012.03.094

3. Laufenberg, G., Kunz, B., \& Nystroem, M. (2003). Transformation of vegetable waste into value added products. Bioresource Technology, 87(2), 167-198. PMid:12765356. http://dx.doi. org/10.1016/S0960-8524(02)00167-0.

4. Leceta, I. A., Etxabide, L., Cabezudo, S., De La Caba, K., \& Guerrero, P. (2014). Bio-based films prepared with byproducts and wastes: environmental assesment. Journal of Cleaner Production, 64, 218-227. http://dx.doi.org/10.1016/j. jclepro.2013.07.054.

5. Vanin, F. M., Sobral, P. J. A., Menegalli, F. C., Carvalho, R. A., \& Habitante, A. M. Q. B. (2005). Effects os plasticizers and their concentrations on thermal and functional properties of gelatin-based films. Food Hydrocolloids, 19(5), 899-907. http://dx.doi.org/10.1016/j.foodhyd.2004.12.003.

6. Pelissari, F. M., Andrade-Mahecha, M. M., Sobral, P. J. A., \& Menegalli, F. C. (2013). Comparative study on the properties of flour and starch films of plantain bananas (Musa paradisiaca). Food Hydrocolloids, 30(2), 681-690. http://dx.doi.org/10.1016/j. foodhyd.2012.08.007.

7. American Society for Testing and Materials-ASTM. (2009). Designation D882-09: standard test method for tensile properties of thin plastic sheeting. West Conshohocken: ASTM. Annual book of ASTM standards.

8. Liu, F., Antoniou, J., Li, Y., Ma, J., \& Zhong, F. (2015). Effect of sodium acetate and drying temperature on physicochemical and thermomechanical properties of gelatin films. Food Hydrocolloids, 45, 140-149. http://dx.doi.org/10.1016/j. foodhyd.2014.10.009.

9. Colla, E., Sobral, P. J. A., \& Menegalli, F. C. (2006). Amaranthus cruentus flour edible films: influence of stearic acid addition, plasticizer concentration, and emulsion stirring speed on water vapor permeability and mechanical properties. Journal of Agricultural and Food Chemistry, 54(18), 6645-6653. PMid:16939322. http://dx.doi.org/10.1021/jf0611217.

10. Mei, J., Yuan, Y., Wu, Y., \& Li, Y. (2013). Characterization of edible starch-chitosan film and its application in the storage of Mongolian cheese. International Journal of Biological Macromolecules, 57, 17-21. PMid:23500443. http://dx.doi. org/10.1016/j.ijbiomac.2013.03.003.

11. Wang, L., Dong, Y., Men, H., Tong, J., \& Zhou, J. (2013). Preparation and characterization of active films based on chitosan incorporated tea polyphenols. Food Hydrocolloids, 32(1), 35-41. http://dx.doi.org/10.1016/j.foodhyd.2012.11.034.

12. Tongnuanchan, P., Benjakul, S., \& Prodpran, T. (2013). Physico-chemical properties, morphology and antioxidant activity of film from fish skin gelatin incorporated with root essential oils. Journal of Food Engineering, 117(3), 350-360. http://dx.doi.org/10.1016/j.jfoodeng.2013.03.005.
13. Martucci, J. F., \& Ruseckaite, R. A. (2009). Biodegradation of three-layer laminate films based on gelatin under indoor soil conditions. Polymer Degradation \& Stability, 94(8), 1307-1313. http://dx.doi.org/10.1016/j.polymdegradstab.2009.03.018.

14. Gennadios, A., \& Weller, C. L. (1994). Moisture adsorption by grain protein films. Transactions of the ASAE, 37(2), 535-539. http://dx.doi.org/10.13031/2013.28109.

15. Al-Hassan, A. A., \& Norziah, M. H. (2012). Starch-gelatin edible films: water vapor permeability and mechanical properties as affected by plasticizers. Food Hydrocolloids, 26(1), 108-117. http://dx.doi.org/10.1016/j.foodhyd.2011.04.015.

16. Cha, D. S., \& Chinnan, M. S. (2004). Biopolymer-based antimicrobial packaging: a review. Critical Reviews in Food Science and Nutrition, 44(4), 223-237. http://dx.doi. org/10.1080/10408690490464276.

17. Carvalho, C. W. P., Ascheri, J. L. R., \& Galdeano, M. C. (2014). Filmes compostos biodegradáveis a base de amido de mandioca e proteina de soja. Polímeros: Ciência e Tecnologia, 24(5), 587-595. http://dx.doi.org/10.1590/0104-1428.1355.

18. Cozmuta, A. M., Turila, A., Apjok, R., Ciocian, A., \& Cozmuta, L. M. (2015). Preparation and characterization of improved gelatin films incorporating hemp and sage oils. Food Hydrocolloids, 49, 144-155. http://dx.doi.org/10.1016/j.foodhyd.2015.03.022.

19. Yang, L., \& Paulson, A. T. (2000). Effects of lipids on mechanical and moisture barrier properties of edible gellan film. Food Research International, 33(7), 571-578. http:// dx.doi.org/10.1016/S0963-9969(00)00093-4.

20. Hosseini, S. F., Rezaei, M., Zandi, M., \& Ghavi, F. F. (2013). Preparation and functional properties of fish gelatin-chitosan blend edible films. Food Chemistry, 136(3-4), 1490-1495. PMid:23194553. http://dx.doi.org/10.1016/j.foodchem.2012.09.081.

21. Garrido, T. A., Etxabide, A., Leceta, S., Cabezudo, S., de la Caba, K., \& Guerrero, P. (2014). Valorization of soya by-products for sustainable packaging. Journal of Cleaner Production, 64, 228-233. http://dx.doi.org/10.1016/j.jclepro.2013.07.027.

22. Azerado, H. C. M., Mattoso, L. H. C., Avena-Bustillos, R. J., Ceotto, G., Fo., Munford, M. L., \& Wood, D. (2010). Nanocellulose reinforced chitosan composite films as affected by nanofiller loading and plasticizer content. Journal of Food Science, 75(1), 1-7. PMid:20492188. http://dx.doi. org/10.1111/j.1750-3841.2009.01386.x.

23. Dias, A. B., Müller, C. M. O., Larotonda, F. D. S., \& Laurindo, J. B. (2010). Biodegradable films based on rice starch and rice flour. Journal of Cereal Science, 51(2), 213-219. http://dx.doi. org/10.1016/j.jcs.2009.11.014.

24. Sothornvit, R., \& Krochta, J. M. (2001). Plasticizer effect on mechanical properties of $\beta$-lactoglobulin films. Journal of Food Engineering, 50(3), 149-155. http://dx.doi.org/10.1016/ S0260-8774(00)00237-5.

25. Chiumarelli, M., \& Hubinger, M. D. (2012). Stability, solubility, mechanical and barrier properties of cassava starch: Carnauba wax edible coatings to preserve fresh-cut apples. Food Hydrocolloids, 28(1), 59-67. http://dx.doi.org/10.1016/j. foodhyd.2011.12.006.

26. Shellhammer, T. H., \& Krochta, J. M. (1997). Whey protein emulsion film performance as affected by lipid type and amount. Journal of Food Science, 62(2), 390-394. http://dx.doi. org/10.1111/j.1365-2621.1997.tb04008.x.

27. Arfat, Y. A., Benjakul, S., Prodpran, T., \& Osako, K. (2014). Development and characterisation of blend films based on fish protein isolate and fish skin gelatin. Food Hydrocolloids, 39, 58-67. http://dx.doi.org/10.1016/j.foodhyd.2013.12.028.

28. Bodini, R. B., Sobral, P. J. A., Favaro-Trindade, C. S., \& Carvalho, R. A. (2013). Properties of gelatin-based films with added ethanol-propolis extract. LWT - Food Science 
and Technology, 51(1), 104-110. http://dx.doi.org/10.1016/j. lwt.2012.10.013.

29. Ghasemlou, M., Khodaiyan, F., Oromiehie, A., \& Yarmand, M. S. (2011). Characterization of edible emulsified films with low affinity to water based on kefiran and oleic acid. International Journal of Biological Macromolecules, 49(3), 378-384. PMid:21640752. http://dx.doi.org/10.1016/j. ijbiomac.2011.05.013.

30. Nur Hanani, Z. A., Roos, Y. H., \& Kerry, J. P. (2012). Use of beef, pork and fish gelatin sources in the manufacture of films and assessment of their composition and mechanical properties. Food Hydrocolloids, 29(1), 144-151. http://dx.doi. org/10.1016/j.foodhyd.2012.01.015.

31. Denavi, G. A., Pérez-Mateos, M., Añón, M. C., Montero, P., Mauri, A. N., \& Gómez-Guillén, M. C. (2009). Structural and functional properties of soy protein isolate and cod gelatin blend films. Food Hydrocolloids, 23(8), 2094-2101. http:// dx.doi.org/10.1016/j.foodhyd.2009.03.007.

32. McHugh, T. H., Avena-Bustillos, R., \& Krochta, J. M. (1993). Hydrophilic edible films: modified procedure for water vapor permeability and explanation of thickness effects. Journal of Food Science, 58(4), 899-903. http://dx.doi. org/10.1111/j.1365-2621.1993.tb09387.x.

33. Dias, T. P., Grosso, C. R. F., Andreuccetti, C., Carvalho, R. A., Galicia-García, T., \& Martinez-Bustos, F. (2013). Effect of the addition of soy lecithin and yucca schidigera extract on the properties of gelatin and glycerol based biodegradable films. Polímeros: Ciência e Tecnologia, 23(3), 339-345. http:// dx.doi.org/10.4322/polimeros.2013.005.

34. Sobral, P. J. A., \& Ocuno, D. (2000). Water vapor permeability of myofibrillar protein based films. Brazilian Journal of Food Technology, 3, 5.

35. López, O. V., \& García, M. A. (2012). Starch films from a novel (Pachyrhizus ahipa) and conventional sources: development and characterization. Materials Science and Engineering, 32(7), 1931-1940. http://dx.doi.org/10.1016/j.msec.2012.05.035.

36. Martins, J. T., Cerqueira, M. A., \& Vicente, A. A. (2012). Influence of $\alpha$-tocopherol on physicochemical properties of chitosan-based films. Food Hydrocolloids, 27(1), 220-227. http://dx.doi.org/10.1016/j.foodhyd.2011.06.011.
37. Jiang, M., Liu, S., Du, X., \& Wang, Y. (2010). Physical properties and internal microstructures of films made from catfish skin gelatin and triacetin mixtures. Food Hydrocolloids, 24(1), 105-110. http://dx.doi.org/10.1016/j.foodhyd.2009.08.011.

38. Hoque, M. S., Benjakul, S., \& Prodpran, T. (2011). Properties of film from cuttlefish (Sepia pharaonis) skin gelatin incorporated with cinnamon, clove and star anise extracts. Food Hydrocolloids, 25(5), 1085-1097. http://dx.doi.org/10.1016/j. foodhyd.2010.10.005.

39. Nuthong, P., Benjakul, S., \& Prodpran, T. (2009). Characterization of porcine plasma protein-based films as affected by pretreatment and cross-linking agents. International Journal of Biological Macromolecules, 44(2), 143-148. PMid:19059429. http:// dx.doi.org/10.1016/j.ijbiomac.2008.11.006.

40. Seyedi, S., Koocheki, A., Mohebbi, M., \& Zahedi, Y. (2015). Improving the physical and moisture barrier properties of Lepidium perfoliatum seed gum biodegradable film with stearic and palmitic acids. International Journal of Biological Macromolecules, 77, 151-158. PMid:25795389. http://dx.doi. org/10.1016/j.ijbiomac.2015.03.005.

41. Ma, W., Tang, C. H., Yin, S. W., Yang, X. Q., Wang, Q., Liu, F., \& Wei, Z. H. (2012). Characterization of gelatin-based edible films incorporated with olive oil. Food Research International, 49(1), 572-579. http://dx.doi.org/10.1016/j.foodres.2012.07.037.

42. Tongnuanchan, P., Benjakul, S., \& Prodpran, T. (2014). Structural, morphological and thermal behaviour characterisations of fish gelatin film incorporated with basil and citronella essential oils as affected by surfactants. Food Hydrocolloids, 41, 33-43. http://dx.doi.org/10.1016/j.foodhyd.2014.03.015.

43. Martucci, J. F., \& Ruseckaite, R. A. (2015). Biodegradation behavior of three-layer sheets based on gelatin and poly (lactic acid) buried under indoor soil conditions. Polymer Degradation \& Stability, 116, 36-44. http://dx.doi.org/10.1016/j. polymdegradstab.2015.03.005.

Received: Nov. 09, 2015

Revised: May 18, 2016

Accepted: June 18, 2016 